\title{
Pengaruh Reliability, Responsiveness, Assurance, Empathy dan Tangibles Terhadap Kepuasan Konsumen GrabBike
}

\author{
Lusiana $^{1^{*}}$, Salamun Pasda ${ }^{2}$, Mustari ${ }^{3}$, Muh. Ihsan Said ${ }^{4}$, Muhammad Hasan ${ }^{5}$ \\ 1,2,3,4,5 Pendidikan Ekonomi, Universitas Negeri Makassar \\ 1'Email: lusianaarsyad83@gmail.com, ${ }^{2}$ Email: salpasda035@gmail.com, ${ }^{3}$ Email: mustari72hm@ gmail.com, \\ ${ }^{4}$ Email: m.ihsansaid@unm.ac.id, ${ }^{5}$ Email:m.hasan@unm.ac.id \\ "Corresponding Author
}

\begin{abstract}
Abstrack. The purpose of this research are to see how reliability, responsiveness, assurance, empathy and tangibles affect the satisfaction of customer users of online transport services to UNM Economic students. Research conducted a method survey with quantitative approach. The population in this research is all students using grab bike online transport, ranging from 2016-2019 to 206 people. Sampling samples using technical samples of random sampling are 67 people. The instruments used to collect data are instruments of questionnaire, observation, and documentation. The data analysis technique used are regression analysis and hypothetical testing with $\mathrm{T}$ and $\mathrm{F}$. data processing used SPSS version 21 for windows software. Research results show that variable as reliability, responsiveness, assurance, empathy, and tangibles are partial to positive and significant effects on users GrabBike online transport satisfaction. Simultaneously there is a positive and significant influence between reliability variables, responsiveness, assurance, empathy and tangibles to the consumer satisfaction users of GrabBike online transport services.
\end{abstract}

Keywords: Reliability; Responsiveness; Assurance; Empathy; Tangibles; Consumer satisfaction

\begin{abstract}
Abstrak. Penelitian ini bertujuan untuk mengetahui pengaruh reliability, responsiveness, assurance, empathy dan tangibles terhadap kepuasan konsumen pengguna jasa transportasi online GrabBike pada mahasiswa Prodi Pendidikan Ekonomi UNM. Penelitian menggunakan metode survey dengan pendekatan kuantitatif. Populasi dalam penelitian ini adalah seluruh mahasiswa pengguna jasa transportasi online GrabBike mulai dari angkatan 2016-2019 sebanyak 206 orang. Penarikan sampel dengan teknik sample random sampling sebanyak 67 orang. Instrument yang digunakan untuk mengumpulkan data adalah angket, observasi dan dokumentasi. Teknik analisis data yang digunakan adalah analisis regresi berganda dan pengujian hipotesis dengan uji t dan uji F. Pengolahan data menggunakan software SPPS Versi 21 for windows. Hasil penelitian menunjukkan bahwa variabel reliability, responsiveness, assurance, empathy dan tangibles secara parsial berpengaruh positif dan signifikan terhadap kepuasan konsumen pengguna jasa transportasi online GrabBike. Secara simultan terdapat pengaruh yang positif dan signifikan antara variabel reliability, responsiveness, assurance, empathy dan tangibles terhadap kepuasan konsumen pengguna jasa transportasi online GrabBike.
\end{abstract}

Kata Kunci: Reliability; Responsiveness; Assurance; Empathy; Tangibles; Kepuasan konsumen

\section{PENDAHULUAN}

Kehadiran jasa transportasi online berbasis digital seperti GrabBike melalui aplikasi Grab sangat berpengaruh bagi mahasiswa dalam segala aktivitas secara cepat dan efisien terutama untuk mahasiswa yang tidak memiliki kendaraan pribadi sedangkan jarak tempuh dari rumah ke kampus lumayan jauh. Transformasi teknologi yang berbasis perangkat lunak (aplikasi) terus mengalami perkembangan dalam membantu kehidupan ekonomi manusia termasuk untuk pengelolaan bisnis (Rahmatullah et al., 2020).

Menurut Kotler (2009), jasa atau pelayanan adalah setiap tindakan atau kegiatan yang dapat ditawarkan oleh satu pihak kepada pihak yang lain, yang pada dasarnya tidak berwujud dan tidak mengakibatkan kepemilikan sesuatu. Dengan ini, mahasiswa cukup memesan GrabBike melalui aplikasi secara online dan nantinya akan dijemput oleh driver yang merespon pesanan. Transaksi pembayaran dilakukan saat konsumen sampai ke tujuan kepada driver. Tarif yang ditetapkan pun berbeda sesuai jarak yang di tempuh dalam kilometer.

Keterbatasan dalam aspek teknik pemasaran menjadi salah satu kendala dalam pengembangan industri (Hasyim \& Hasan, 2017). Untuk mendapatkan loyalitas para konsumen perusahaan harus memiliki strategi pemasaran yang baik dan tepat agar dapat mempertahankan bahkan meningkatkan loyalitas konsumennya. Salah satu faktor yang mempengaruhi loyalitas 
konsumen adalah kepuasan yang dirasakan konsumen. Sangadji \& Sopiah (2016), kepuasan konsumen adalah perbandingan antara persepsi konsumen terhadap jasa yang diterima dan harapannya sebelum menggunakan jasa tersebut. Kepuasan konsumen digunakan sebagai salah satu bahan pertimbangan dalam penentuan tingkat keberhasilan dari palayanan/ jasa yang diberikan.

Tjiptono \& Gregorius (2012) menyatakan kepuasan konsumen adalah situasi yang ditunjukkan oleh konsumen ketika mereka menyadari bahwa kebutuhan dan keinginannya sesuai dengan yang diharapkan serta terpenuhi secara baik. Baik atau tidaknya pelayanan jasa bergantung pada kemampuan penyedia jasa dalam memenuhi harapan yang sesuai dengan keinginan konsumen. Pelayanan dikatakan baik dan memuaskan apabila layanan yang dirasakan sama atau melebihi harapan konsumen. Konsumen yang merasa puas pada produk/ jasa yang dibeli dan digunakannya akan kembali menggunakan jasa/ produk yang ditawarkan (Kotler dan Keller, 2009).

Kotler (2008) menyatakan bahwa yang menjadi indikator kepuasan konsumen adalah: a) Menjadi lebih setia; b) Membeli lebih banyak jika perusahaan memperkenalkan produk baru dan menyempurnakan produk yang ada; c) Memberikan komentar yang menguntungkan tentang perusahaan dan produknya; d) Kurang memberikan perhatian pada merek dan iklan pesaing dan kurang sensitif terhadap harga; e) Memberikan gagasan produk atau jasa pada perusahaan; dan d) Membutuhkan biaya pelayanan yang lebih kecil daripada konsumen baru karena transaksi menjadi lebih rutin.

Sedangkan menurut Rivai (2019), indikator yang digunakan untuk mengukur kepuasan konsumen diantaranya: a) Keinginan/harapan konsumen untuk tetap menggunakan jasa. b) Keinginan konsumen untuk merekomendasikan kepada orang lain. c) Puas atas kualitas pelayanan yang diberikan.

Kepuasaan dipengaruhi oleh dimensi kualitas pelayanan, seperti yang dikemukanan Kotler \& Keller (2009) dimensi kualitas pelayanan berdasarkan urutan tingkat pentingnya ada lima, yakni reliability (keandalan) yaitu kemampuan untuk melaksanakan jasa yang dijanjikan dengan andal dan akurat, responsiveness (daya tanggap) yaitu kesediaan membantu konsumen dan memberikan jasa dengan cepat, assurance (jaminan) yaitu karyawan mampu menumbuhkan kepercayaan konsumen terhadap perusahaan dan perusahaan bisa menciptakan rasa aman kepada konsumen, empathy (empati) yaitu suatu usaha untuk memperhatikan dan memberikan perhatian pribadi kepada konsumen dan tangibles (bukti fisik) yaitu penampilan fasilitas fisik, peralatan, personel, dan bahan komunikasi, seperti gedung kantor, atribut yang dikenakan karyawan, peralatan untuk menyalurkan jasa dan penampilan karyawan.

Penelitian yang dilakukan oleh Apriyani \& Sunarti (2017), dengan judul pengaruh kualitas pelayanan terhadap kepuasan konsumen (survei pada konsumen The Little A Coffee Shop Sidoarjo). Hasil penelitiannya menunjukkan bahwa variabel dimensi tangible (bukti langsung) (X1), reliability (keandalan) (X2), responsiveness (daya tanggap) (X3), assurance (jaminan) (X4) dan empathy (empati) (X5) berpengaruh secara positif dan signifikan terhadap kepuasan konsumen.

Ramadhan (2019), dalam penelitiannya yang berjudul kualitas pelayanan sebagai determinan kepuasan pelanggan jasa transportasi GrabBike di Yogyakarta. Hasil penelitiannya menunjukkan bahwa variabel dimensi tangible (bukti langsung) (X1), reliability (keandalan) (X2), responsiveness (daya tanggap) (X3), assurance (jaminan) (X4) dan empathy (empati) (X5) berpengaruh secara positif dan signifikan terhadap kepuasan pelanggan jasa transportasi GrabBike di Yaogyakarta.

Selain itu penelitian yang dilakukan oleh Sari (2018), dengan judul pengaruh dimensi kualitas pelayanan (tangible, empathy, responsiveness, reliability, dan assurance) terhadap kepuasan pelanggan angkutan ojek online Go-Jek pada mahasiswa jurusan Ilmu Pengetahuan Sosial Fakultas Keguruan dan Ilmu Pendidikan Universitas Lampung. Hasil penelitiannya juga menunjukkan bahwa varibel dimensi Tangible (X1), Empathy (X2), Responsiveness (X3), Reliability (X4), dan Assurance (X5) berpengaruh secara positif dan signifikan terhadap kepuasan pelanggan.

Berdasarkan hasil observasi pendahuluan dari kelima dimensi tersebut masih terlihat adanya ketidakpuasan konsumen atas pelayanan yang diterimanya. Hal ini terlihat dari reliability (keandalan) yakni ketidaktepatan driver GrabBike dalam menganalisa jalan tercepat untuk mencapai tujuan yang menyebabkan terjadinya penambahan waktu atau keterlambatan konsumen. Responsiveness (daya tanggap), GrabBike tidak menyediakan uang kecil untuk 
kembalian dari transaksi pembayaran dan masih adanya driver yang belum menggunakan system pembayaran OVO. Assurance (jaminan), driver yang termuat pada estimasi aplikasi berbeda dengan driver yang datang menjemput konsumen. Empathy (empati), driver GrabBike kurang baik dalam menanggapi keluhan konsumen. Terakhir tangibles (bukti fisik) dimana driver Grab tidak menggunakan atribut lengkap dari PT.Grab seperti jaket dan helm, kendaraan yang dipakai kurang terawat (ban kendaraan yang sudah gundul) dan tidak bersih. Helm yang disediakan untuk konsumen pun seringkali kotor tidak terawat.

Dari berbagai fenomena yang terjadi menunjukkan masih adanya kelemahankelemahan driver GrabBike dalam memberikan pelayanan kepada konsumen. Walaupun jasa transportasi online GrabBike yang ada saat ini masih memiliki berbagai kekurangan dalam pelayanannya akan tetapi konsumen tetap menggunakan jasa transportasi online tersebut bahkan konsumen yang menggunakannya semakin meningkat, peningkatan terjadi terutama dikalangan mahasiswa. Hal ini menarik diteliti untuk mengetahui faktor-faktor yang melatarbelakanginya. Oleh karena itu peneliti tertarik untuk meneliti lebih lanjut terkait pengaruh reliability (keandalan), responsiveness (daya tanggap), assurance (jaminan), empathy (empati) dan tangibles (bukti fisik) terhadap Kepuasan Konsumen Pengguna Jasa Transportasi Online GrabBike pada Mahasiswa Prodi Pendidikan Ekonomi UNM.

Penelitian ini bertujuan untuk mengetahui pengaruh reliability (keandalan), responsiveness (daya tanggap), assurance (jaminan), empathy (empati) dan tangibles (bukti fisik) terhadap Kepuasan Konsumen Pengguna Jasa Transportasi Online GrabBike pada Mahasiswa Prodi Pendidikan Ekonomi UNM.

Penelitian ini berkontribusi pada literatur tentang kepuasan konsumen kajian tentang dimensi kualitas pelayanan (reliability, responsiveness, assurance, empathy dan tangibles) yang mempengaruhi kepuasan konsumen serta meningkatkan mutu pelayanan transportasi sesuai dengan harapan konsumen.

\section{METODE PENELITIAN}

Penelitian ini menggunakan metode penelitian survey dengan pendekatan kuantitatif. Penelitian ini untuk mengetahui pengaruh reliability $\left(\mathrm{X}_{1}\right)$, responsiveness $\left(\mathrm{X}_{2}\right)$, assurance $\left(\mathrm{X}_{3}\right)$, empathy $\left(\mathrm{X}_{4}\right)$ dan tangibles $\left(\mathrm{X}_{5}\right)$ terhadap kepuasan konsumen pengguna jasa transportasi online GrabBike (Y) baik secara parsial maupun simultan.

Penelitian ini khusus dilakukan pada mahasiswa Prodi Pendidikan Ekonomi Universitas Negeri Makassar yang khusus mengkaji kepuasan mahasiswa selaku konsumen pengguna jasa transportasi online GrabBike beralamatkan di jalan A. P. Pettarani Kampus UNM Gunungsari Baru. Adapun populasi dalam penelitian ini adalah seluruh mahasiswa Prodi Pendidikan Ekonomi pengguna jasa transportasi online GrabBike mulai dari angkatan 2016-2019 sebanyak 206 orang. Pengambilan sampel menggunakan teknik simple random sampling dengan rumus Slovin sehingga diperoleh sampel sebanyak 67 orang. Selanjutnya penentuan jumlah sampel perangkatan digunakan teknik proportunate random sampling.

Teknik pengumpulan data yang digunakan dalam penelitian ini adalah kuesioner/ angket tertutup. Instrumen dalam penelitian ini menggunakan kuesioner dengan skala likert yang digunakan untuk mengukur adalah reliability, responsiveness, assurance, empathy dan tangibles. Penetapan skor diberikan kepada jawaban setiap responden dengan nilai 1 sampai 5 dengan asumsi jawaban (1) sangat tidak setuju, (2) tidak setuju, (3) ragu-ragu, (4) setuju, dan (5) sangat setuju. Pengujian instrumen yang digunakan dalam penelitian ini adalah uji validitas dan uji reliabilitas.

Teknik analisis data yang digunakan dalam penelitian ini adalah uji statistik deskriptif, dan uji statistik inferensial. Teknik analisis data yang digunakan adalah analisis regresi berganda dan pengujian hipotesis dengan uji $\mathrm{t}$ dan uji $\mathrm{F}$. Pengolahan data menggunakan software SPPS Versi 21 for windows.

\section{HASIL DAN PEMBAHASAN}

Validitas yang digunakan dalam penelitian ini (content validity) menggambarkan kesesuaian sebuah pengukur data dengan apa yang akan diukur (Supardi, 2017). Pengujian validitas ini dilakukan dengan menghitung korelasi (r) antara data masing-masing pernyataan skor total memakai rumus teknik korelasi Product Moment Pearson. Suatu instrument dinyatakan valid apabila koefisisen $r$ hitung lebih besar dibandingkan koefisisen korelasi $\mathrm{r}$ tabel pada taraf signifikan 5\% (Ghozali, 2010). Hasil penelitian menunjukkan bahwa koefisisen $r$ hitung dari setiap item > $\mathrm{r}$ tabel pada taraf signifikan 5\%, sehingga dinyatakan masingmasing item variabel adalah valid. 
Pengambilan keputusan reliabilitas, suatu instrumen dikatakan reliabel jika nilai Croanbach Alpha lebih besar dari 0,60 (Ghozali, 2010). Hasil pengujian reliabilitas dapat dilihat pada Tabel 1 sebagai berikut :

Tabel 1. Uji Reliabilitas

\begin{tabular}{lccc}
\hline \multicolumn{1}{c}{ Variabel } & Cronbach Alpha & r- Tabel & Kriteria \\
\hline Reliability & 0,716 & 0,600 & Reliabel \\
Responsiveness & 0,802 & 0,600 & Reliabel \\
Assurance & 0,701 & 0,600 & Reliabel \\
Empathy & 0,637 & 0,600 & Reliabel \\
Tangibles & 0,687 & 0,600 & Reliabel \\
Kepuasan Konsumen & 0,733 & 0,600 & Reliabel \\
\hline
\end{tabular}

Sumber: Hasil Olah Data, 2020

Hasil pengujian reliabilitas menunjukkan bahwa variabel reliability memiliki nilai sebesar 0,716 ; variabel responsiveness memiliki nilai sebesar 0,802; variabel assurance memiliki nilai sebesar 0,701; variabel empathy memiliki nilai sebesar 0,637; variabel tangibles memiliki nilai sebesar 0,687 dan variabel kepuasan konsumen memiliki nilai sebesar 0,733 . Sehingga dapat disimpulkan bahwa seluruh butir pernyataan dalam variabel tersebut reliable, karena seluruh variabel mempunyai nilai Croanbach Alpha > 0,60 .

Analisis statistik inferensial yang digunakan dalam penelitian ini meliputi uji prasyarat (uji normalitas dan uji linearitas) dan uji hipotesis (analisis regresi berganda, uji t, uji f, determinasi dan korelasi).

Pengujian normalitas dengan menggunakan uji normalitas One-Sample Kolmogorov-Smirnov Test dapat dilihat pada tabel 2.

Tabel 2. Uji Normalitas

\begin{tabular}{lcc}
\hline \multicolumn{1}{c}{ Variabel } & Asymp. Sig & Keterangan \\
\hline Reliability & 0,061 & Normal \\
Responsiveness & 0,079 & Normal \\
Assurance & 0,406 & Normal \\
Empathy & 0,052 & Normal \\
Tangibles & 0,105 & Normal \\
\hline
\end{tabular}

Sumber: Hasil Olah Data, 2020

Variabel dikatakan mempunyai distribusi normal pada taraf signifikan 5\% jika nilai Asymp. Sig lebih dari 0,05 (Ghozali, 2010). Dari hasil uji normalitas variabel reliability, responsiveness, assurance, empathy dan tangibles memperoleh nilai Asymp. Sig > 0,05 sehingga dapat disimpulkan bahwa kelima variabel berdistribusi normal.
Hasil pengujian linearitas dengan menggunakan uji linearitas deviation from linearity dapat dilihat pada Tabel 3.

Tabel 3. Uji Linearitas

\begin{tabular}{lcc}
\hline \multicolumn{1}{c}{ Variabel } & $\begin{array}{c}\text { Deviation } \\
\text { From } \\
\text { Linearity }\end{array}$ & $\begin{array}{c}\text { Keterangan } \\
\text { Hubungan }\end{array}$ \\
\hline Reliability & 0,058 & Linear \\
Responsiveness & 0,209 & Linear \\
Assurance & 0,266 & Linear \\
Empathy & 0,074 & Linear \\
Tangibles & 0,895 & Linear \\
\hline
\end{tabular}

Sumber: Hasil Olah Data, 2020

Variabel dikatakan mempunyai hubungan yang linier apabila nilai signifikan deviation from linearity lebih besar dari taraf signifikan 0,05 (Ghozali, 2010). Dari hasil uji linearitas variabel reliability, responsiveness, assurance, empathy dan tangibles memperoleh nilai deviation from linearity > 0,05 sehingga dapat disimpulkan adanya hubungan yang linear.

Berdasarkan hasil analisis regersi berganda melalui aplikasi SPSS Versi 21 for windows diperoleh persamaan regresi sebagai berikut:

$\mathrm{Y}=1,646+0,780 \mathrm{X} 1+$

$0,325 \times 2+0,220 \times 3+0,245 \times 4+0,256 \times 5$

Besarnya kontribusi variabel reliability, responsiveness, assurance, empathy dan tangibles terhadap kepuasan konsumen pengguna jasa transportasi online GrabBike diketahui dari nilai koefisien determinasi $\left(\mathrm{R}^{2}\right)$ sebesar 0,814 atau sebesar $81,4 \%$. Ini berarti $81,4 \%$ variabel kepuasan konsumen pengguna jasa transportasi online GrabBike dipengaruhi oleh variabel reliability, responsiveness, assurance, empathy dan tangibles sedangkan sisanya 18,6\% dipengaruhi oleh faktor-faktor lain yang tidak terdapat di dalam model penelitian. 
Tabel 4. Hasil Uji Regresi Berganda

\begin{tabular}{lrrrrrr}
\hline \multicolumn{1}{c}{ Variabel } & B & \multicolumn{1}{c}{ Std. Error } & Beta & t & \multicolumn{1}{l}{ Sig. } & $\mathrm{R}$ \\
\hline (Constant) & 1.646 & 1.335 & & 1.233 & .222 & \\
Reliability & .780 & .134 & .444 & 5.840 & .000 & 0,809 \\
Responsiveness & .325 & .138 & .204 & 2.361 & .021 & 0,762 \\
Assurance & .220 & .106 & .147 & 2.070 & .043 & 0,664 \\
Empathy & .245 & .116 & .160 & 2.117 & .038 & 0,672 \\
Tangibles & .256 & .099 & .175 & 2.587 & .012 & 0,785 \\
F & $: 53.386$, sig.0,000 & & & & & \\
Korelasi (R) $: 0,902$ & & & & & \\
Determinasi (R $\mathrm{R}^{2}: 0,814$ & & & & & \\
\hline
\end{tabular}

Sumber: Hasil Olah Data, 2020

$\begin{array}{llr}\text { Pengaruh reliability secara parsial terhadap } \\ \text { kepuasan } & \text { konsumen pengguna jasa } \\ \text { transportasi } & \text { online GrabBike pada } \\ \text { mahasiswa prodi pendidikan ekonomi UNM }\end{array}$

Berdasarkan hasil penelitian menunjukkan bahwa variabel reliability berpengaruh positif dan signifikan terhadap kepuasan konsumen pengguna jasa transportasi online GrabBike, sehingga dapat dikatakan bahwa konsumen merasa puas atas pelayanan reliability (keandalan) yang diberikan oleh driver GrabBike karena harapan konsumen sebelum dan setelah menerima pelayanan reliability (keandalan) sesuai bahkan melebihi harapan konsumen. Kepuasan konsumen ini diwujudkan melalui: 1) Kecepatan driver melayani konsumen; 2) Kemudahan dalam pemesanan GrabBike; dan 3) Adanya pemberitahuan/konfirmasi pelaksanaan pelayanan. Hal tesebut membuat konsumen tertarik untuk menggunakannya kembali bahkan merekomendasikan kepada orang lain untuk menggunakannya juga.

Hasil penelitian ini sejalan dengan temuan Ramadhan (2019) yang menjelaskan bahwa adanya pengaruh yang positif dan signifikan reliability (keandalan), responsiveness (daya tanggap), assurance (jaminan), empathy (empati) dan tangible (bukti langsung) terhadap kepuasan pelanggan jasa transportasi GrabBike di Yogyakarta.

Pengaruh responsiveness secara parsial terhadap kepuasan konsumen pengguna jasa transportasi online GrabBike pada mahasiswa prodi pendidikan ekonomi UNM

Hasil penelitian menunjukkan bahwa variabel responsiveness berpengaruh positif dan signifikan terhadap kepuasan konsumen pengguna jasa transportasi online GrabBike, sehingga dapat dikatakan bahwa konsumen merasa puas atas pelayanan responsiveness (daya tanggap) yang diberikan oleh driver GrabBike karena harapan konsumen sebelum dan setelah menerima pelayanan responsiveness (daya tanggap) sesuai bahkan melebihi harapan konsumen. Kepuasan konsumen ini diwujudkan melalui: 1) Tanggap terhadap keluhan konsumen; 2) Kesediaan merespon permintaan bantuan konsumen; dan 3) Kemudahan dalam transaksi pembayaran. Hal ini membuat konsumen tertarik untuk menggunakannya kembali dan merekomendasikan kepada orang lain untuk menggunakannya juga.

Hasil penelitian ini sejalan dengan temuan Apriyani \& Sunarti (2017) yang menjelaskan bahwa terdapat pengaruh secara positif dan signifikan antara variabel tangibles (bukti langsung), reliability (keandalan), responsiveness (daya tanggap), assurance (jaminan) dan empathy (empati) terhadap kepuasan konsumen (Survei Pada Konsumen The Little A Coffee Shop Sidoarjo).

Pengaruh assurance secara parsial terhadap kepuasan konsumen pengguna jasa transportasi online GrabBike pada mahasiswa prodi pendidikan ekonomi UNM

Selain itu hasil penelitian ini juga menunjukkan bahwa variabel assurance berpengaruh positif dan signifikan terhadap kepuasan konsumen pengguna jasa transportasi online GrabBike, sehingga dapat dikatakan bahwa konsumen merasa puas atas pelayanan assurance (jaminan) yang diberikan oleh driver GrabBike karena harapan konsumen sebelum dan setelah menerima pelayanan assurance (jaminan) sesuai bahkan melebihi harapan konsumen. Kepuasan konsumen ini diwujudkan melalui: 1) Driver GrabBike yang datang menjemput sesuai dengan estimasi aplikasi; 2) Pengetahuan yang luas terkiat jalan/ alamat yang akan dituju; dan 3) Keterampilan mengemudikan kendaraan. Hal ini membuat konsumen tertarik untuk menggunakannya kembali bahkan merekomendasikan kepada orang lain untuk menggunakannya juga. 
Hasil penelitian ini sejalan dengan temuan Sari (2018) yang menjelaskan bahwa ada pengaruh yang positif dan signifikan jaminan/assurance terhadap kepuasan pelanggan angkutan ojek online GO-JEK pada mahasiswa jurusan Ilmu Pengetahuan Sosial Fakultas Keguruan dan Ilmu Pendidikan Universitas Lampung.

Pengaruh empathy secara parsial terhadap kepuasan konsumen pengguna jasa transportasi online GrabBike pada mahasiswa prodi pendidikan ekonomi UNM

Hasil penelitia juga menunjukkan bahwa variabel empathy berpengaruh positif dan signifikan terhadap kepuasan konsumen pengguna jasa transportasi online GrabBike, sehingga dapat dikatakan bahwa konsumen merasa puas atas pelayanan empathye (empati) yang diberikan oleh driver GrabBike karena harapan konsumen sebelum dan setelah menerima pelayanan empathye (empati) sesuai bahkan melebihi harapan konsumen. Kepuasan konsumen ini diwujudkan melalui: 1) Kesediaan merespon permintaan konsumen; 2) Mengerti keinginan konsumen; dan 3) Membantu menaikkan barang ke sepeda motor. Hal ini membuat konsumen tertarik untuk menggunakannya kembali bahkan merekomendasikan kepada orang lain untuk menggunakannya juga.

Hasil penelitian ini sejalan dengan temuan Apriyani \& Sunarti (2017) yang menjelaskan bahwa terdapat pengaruh secara positif dan signifikan antara variabel tangibles (bukti langsung), reliability (keandalan), responsiveness (daya tanggap), assurance (jaminan) dan empathy (empati) terhadap kepuasan konsumen (Survei Pada Konsumen The Little A Coffee Shop Sidoarjo). Variabel empathy (empati) (X5) merupakan variabel yang mempunyai pengaruh dominan terhadap Kepuasan Konsumen di The Little A Coffee Shop Sidoarjo.

Pengaruh tangibles secara parsial terhadap kepuasan konsumen pengguna jasa transportasi online GrabBike pada mahasiswa prodi pendidikan ekonomi UNM

Hasil penelitian terakhir menunjukkan bahwa variabel tangibles berpengaruh positif dan signifikan terhadap kepuasan konsumen pengguna jasa transportasi online GrabBike, sehingga dapat dikatakan bahwa konsumen merasa puas atas pelayanan fasilitas yang diberikan oleh driver GrabBike karena harapan konsumen sebelum dan setelah menerima pelayanan fasilitas tangibles (bukti fisik) sesuai bahkan melebihi harapan konsumen. Kepuasan konsumen ini diwujudkan melalui: 1) Kelayakan kendaraan menyalurkan jasa; 2) Kebersihan kelengkapan berkendara yang di berikan; dan 3) Menggunakan identitas dari perusahaan. Hal ini membuat konsumen tertarik untuk menggunakannya kembali bahkan merekomendasikan kepada orang lain untuk menggunakannya juga.

Hasil penelitian ini sejalan dengan temuan Sari (2018) yang menemukan bahwa terdapat pengaruh yang positif dan signifikan bukti fisik/tangibles terhadap kepuasan pelanggan angkutan ojek online GO-JEK pada mahasiswa jurusan Ilmu Pengetahuan Sosial Fakultas Keguruan dan Ilmu Pendidikan Universitas Lampung.

Pengaruh reliability, responsiveness, assurance, empathy dan tangibles secara simultan terhadap kepuasan konsumen pengguna jasa transportasi online GrabBike pada mahasiswa prodi pendidikan ekonomi UNM

Berdasarkan hasil pengolahan data menunjukkan bahwa nilai $\mathrm{F}$ sebesar 53.386 dengan sig. $=0,000<0,05$ yang berarti bahwa variabel reliability, responsiveness, assurance, empathy dan tangibles secara simultan berpengaruh signifikan terhadap kepuasan konsumen pengguna jasa transportasi online GrabBike pada mahasiswa Prodi Pendidikan Ekonomi UNM. Berdasarkan hasil uji $t$ menunjukkan bahwa variabel reliability, responsiveness, assurance, empathy dan tangibles secara parsial berpengaruh terhadap kepuasan konsumen pengguna jasa transportasi online GrabBike pada mahasiswa Prodi Pendidikan Ekonomi UNM.

Hasil penelitian ini sejalan dengan temuan Ramadhan (2019) di mana penelitiannya menunjukkan terdapat pengaruh yang positif dan signifikan reliability (keandalan), responsiveness (daya tanggap), assurance (jaminan), empathy (empati) dan tangible (bukti langsung) terhadap kepuasan pelanggan jasa transportasi GrabBike di Yogyakarta.

\section{KESIMPULAN DAN SARAN}

Hasil penelitian ini menunjukkan bahwa variabel reliability (keandalan), responsiveness (daya tanggap), assurance (jaminan), empathy (empati) dan tangibles (bukti fisik) secara parsial berpengaruh terhadap kepuasan konsumen pengguna jasa transportasi online GrabBike pada Mahasiswa Prodi Pendidikan Ekonomi UNM. Konsumen merasa puas atas pelayanan yang 
diterimanya karena harapan konsumen sebelum dan setelah menerima pelayanan sesuai bahkan melebihi harapan konsumen.

Selain itu, reliability (keandalan), responsiveness (daya tanggap), assurance (jaminan), empathy (empati) dan tangibles (bukti fisik) secara simultan juga berpengaruh terhadap kepuasan konsumen pengguna jasa transportasi online GrabBike pada Mahasiswa Prodi Pendidikan Ekonomi UNM. Konsumen merasa puas atas pelayanan dan fasilitas penunjang yang telah diberikan driver GrabBike karena harapan konsumen sebelum dan setelah menerima pelayanan dan fasilitas penunjang sesuai bahkan melebihi harapan konsumen. Sehingga konsumen berminat untuk menggunakan kembali dan menyarankan kepada orang lain untuk menggunakannya. Jika reliability (keandalan), responsiveness (daya tanggap), assurance (jaminan), empathy (empati) dan tangibles (bukti fisik) yang diberikan ditingkatkan maka kepuasan konsumen akan meningkat juga.

\section{DAFTAR RUJUKAN}

Apriyanti, A. D \& Sunarti. (2017). Pengaruh Kualitas Pelayanan Terhadap Kepuasan Konsumen (Survei Pada Konsumen The Little A Coffee Shop Sidoarjo). Jurnal Administrasi Bisni, 5(2), 1-7.

Damayanti, E. R \& Rosyad, U. N. (2018). Pengaruh Kualitas Pelayanan Transportasi Ojek Online Grab Terhadap Kepuasan Pelanggan Menggunakan Grabbike. Jurnal Manajemen Komunikas, 2(1), 600-603.

Gozhali, I. (2010). "Aplikasi Analisis Multivariate dengan Program SPSS". Semarang : UNDIP.

Hasyim, S. H \& Hasan, M. (2017). Strategi Pemberdayaan dan Keunggulan Bersaing Industri Kecil. Prosiding Seminar Nasional Dies Natalis Ke 56 Universitas Negeri Makassar, 1 (1), 185-192.

Kasum, S \& Sularto. (2017). Pengaruh Kualitas Pelayanan dan Promosi terhadap Kepuasan Pelanggan Grabbike di Jakarta Timur. Jurnal Administrasi dan Manajemen, 10(2), 652-660.

Kotler, P \& Amstrong, G. (2008). Prinsip-prinsip Pemasaran. Edisi12. Jilid 1. Jakarta: Erlangga.
Kotler, P \& Keller, K. L. (2009). Manajemen Pemasaran. Edisi 13. Jilid 2. Jakarta: Erlangga.

Rahmatullah, Inanna, Sahade, Nurdiana, Fajriani Azis, \& Bahri. (2020). Utilization of Digital Technology for Management Effectiveness Micro Small and Medium Enterprises. International Journal of Scientific \& Technology Research, 9(4), 1358-1362. Retrieved from www.ijstr.org

Ramadhan, F. (2019). Kualitas Pelayanan sebagai Determinan Kepuasan Pelanggan Jasa Transportasi GrabBike di Yogyakarta. Jurnal Fokus, 9(2), 191-205.

Rivai, K. A. 2019. Pengaruh Kualitas Pelayanan, Harga dan Citra Merek terhadap Kepuasan Konsumen Pengguna Transportasi Ojek Online Grab. Jurnal Riset Manajemen Sains Indonesia (JRMSI). 10(1): 204-225.

Sangadji \& Sopiah. (2016). Perilaku Konsumen. Yogyakarta: Andi Offset.

Sari, H. L. (2018). Pengaruh Dimensi Kualitas Pelayanan (Tangible, Empathy, Responsiveness, Reliability, dan Assurance) terhadap Kepuasan Pelanggan Angkutan Ojek Online Go-Jek pada Mahasiswa Jurusan Ilmu Pengetahuan Sosial Fakultas Keguruan dan Ilmu Pendidikan Universitas Lampung Tahun 2018. Skripsi. Universitas Lampung.

Supardi. (2017). Statistik Penelitian Pendidikan Perhitungan, Penyajian, Penjelasan, Penafsiran, dan Penarikan Kesimpulan. Depok: Rajawali Pers.

Tjiptono, F \& Gregorius ,C. (2012). Service Quality \& Satisfaction Edisi ketiga. Yogyakarta: Andi Offset. 